\title{
Welcome to the 17th volume of Personalized Medicine
}

Ebony Torrington*,1

${ }^{1}$ Future Science Group, Unitec House, 2 Albert Place, London, N3 1QB, UK

*Author for correspondence: e.torrington@futuremedicine.com

\author{
"the scope of Personalized Medicine took a new direction, which primarily focuses on \\ implementation and translation of precision medicine discoveries into clinic, public health, \\ technology and engagement."
}

First draft submitted: 28 November 2019; Accepted for publication: 28 November 2019; Published online: 13 December 2019

Keywords: authorship $\bullet$ education $\bullet$ genomics $\bullet$ personalized medicine $\bullet$ readership $\bullet$ social media $\bullet$ top content

\section{Background}

To all of our readers, we would like to welcome you to Volume 17 of Personalized Medicine. I am pleased to introduce the first issue of 2020 which, as usual, contains a broad spread of content, representing the diverse field of personalized and precision medicine.

This year, the journal was delighted to announce an increase in the impact factor to 1.414 . In addition, the scope of Personalized Medicine took a new direction, which primarily focuses on implementation and translation of precision medicine discoveries into clinic, public health, technology and engagement. Following this new direction, current opinion leaders in these areas were recruited to the Editorial Board [1]. We would like to welcome these new experts to the Editorial Board and note that we are looking forward to working with them as we move into the new year.

\section{Content highlights in 2019}

In Volume 16, we published a large number of high-impact and insightful articles across a diverse range of topics within this ever-evolving field. Table 1 details the five most-read articles published in Personalized Medicine in 2019. At the time of writing (November 2019), our most read article of 2019 was an Editorial entitled "The importance of real-world data to precision medicine" [2]. In this article, D Kalra from the University of Ghent (Ghent, Belgium) highlights the importance of promoting the value of health data research to the public and how this data can deliver health benefits while protecting their privacy.

Another highly read article from this volume was a Perspective by James Snyder et al. entitled "Clinical and research applications of a brain tumor tissue bank in the age of precision medicine" [3]. This work focuses on tissue biobanking and concludes that brain tissue repositories that integrate tissue- and clinical-derived data provide opportunities to improve therapeutic decision making and encourage high impact research in the hopes of improving patient outcome.

This year's Special Focus Issue entitled "Improving Genomics Education" highlighted the importance and latest strategies of genetic and genomic education. The Special Focus Issue also included one of our most read and top-scoring articles on the Altmetric platform in 2019, a Foreword entitled "Educating healthcare providers in the delivery of genomic medicine" [4].

The guest editors, J McCarthy (University of California, CA, USA) and G Patrinos (University of Patras, Greece) discuss the need for education in genomic medicine and the progress being made to identify various teaching methods, including online education, in order to reach healthcare providers at all stages of their careers. Some of the highlights of the Special Focus Issue included a Research Article studying provider engagement of genetic education in oncology [7]; a Special Report highlighting the importance, trends and challenges of undergraduate medical 


\begin{tabular}{|c|c|c|c|c|}
\hline Rank & Title & Author(s) & Volume (issue) & Ref. \\
\hline 1 & The importance of real-world data to precision medicine & Kalra D & Volume 16 (Issue 2) & [2] \\
\hline 2 & $\begin{array}{l}\text { Clinical and research applications of a brain tumor tissue bank in the age of } \\
\text { precision medicine }\end{array}$ & $\begin{array}{l}\text { Snyder J, Poisson LM, Noushmehr H et } \\
\text { al. }\end{array}$ & Volume 16 (Issue 2) & [3] \\
\hline 3 & Educating healthcare providers in the delivery of genomic medicine & McCarthy $\mathrm{J}$ and Patrinos $\mathrm{G}$ & Volume 16 (Issue 3) & [4] \\
\hline 4 & $\begin{array}{l}\text { What will it take to implement genomics in practice? Lessons from the } \\
\text { IGNITE Network }\end{array}$ & $\begin{array}{l}\text { Ginsburg GS, Horowitz CR and Orlando } \\
\text { LA }\end{array}$ & Volume 16 (Issue 4) & [5] \\
\hline 5 & $\begin{array}{l}\text { Preparing next-generation scientists for biomedical big data: artificial } \\
\text { intelligence approaches }\end{array}$ & Moore JH, Boland MR, Camara PG et al. & Volume 16 (Issue 3) & [6] \\
\hline
\end{tabular}

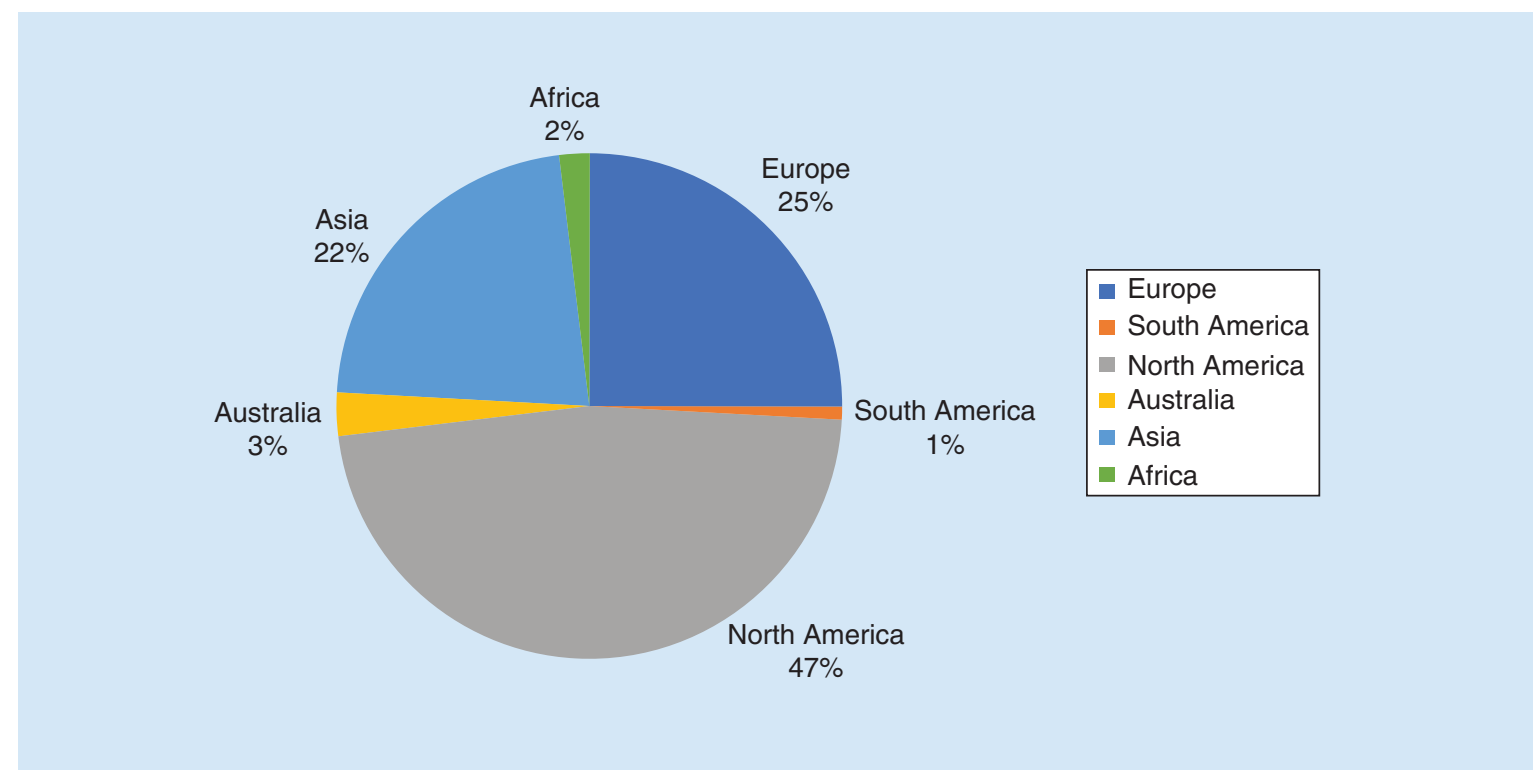

Figure 1. Readership demographics for Personalized Medicine in 2019.

education [8]; and an interview with C Easter (NIH, MD, USA) explaining her most recent work in educating the public on genetics and genomics [9].

The most read Research Article of 2019 was "Characterization offarnesyl diphosphate farnesyl transferase 1 (FDFT1) expression in cancer" [10]. In this work, Tüzmen et al. concluded that FDFT1 gene/protein overexpression is involved in human cancers and in future work, the authors hope to analyze the role of FDFT1 DNA/RNA/protein changes in different types of cancer.

Special mention goes to the following articles, which achieved the journal's highest Altmetric scores in 2019, as we continue our successful partnership with the platform:

- Our highest scoring article of 2019 was "Preparing next-generation scientists for biomedical big data: artificial intelligence approaches" [6], which was also our most mentioned paper on Twitter and the fifth most read Personalized Medicine article of 2019.

- The Review article by Wang et al. entitled "Toward multiomics-based next-generation diagnostics for precision medicine" [11] and the Research Article "APOE genotypes in Lebanon: distribution and association with hypercholesterolemia and Alzheimer's disease" by Shamieh et al. [12]

\section{Readership demographics}

As the precision medicine research community continues to grow, the readership of Personalized Medicine changes. In 2019, our content was most read by experts in the USA (48\%) and Europe (25\%) (Figure 1). While our content continues to have impact across Europe and the West, we expect to see a continued growth in emerging scientific communities and look forward to continuing the circulation of our content to an increasingly global audience. 


\section{Social media}

Personalized Medicine's social media presence has continued to grow throughout 2019 and you can join over 2200 people (at the time of writing) in following the journal on Twitter at @fsgpme [13]. We regularly post journal highlights, including newly published content and issues, offers and the latest news in the field.

\section{Conclusion}

We appreciate all feedback from the personalized and precision medicine communities regarding the direction of our content, especially suggestions of any priority topics in the field that you feel the journal should cover. We welcome unsolicited research, review and opinion article proposals among others and would be delighted to hear from you if you are interested in submitting to the journal.

We would also like to take this opportunity to thank all of our valued Editorial Board members, readers, authors and peer reviewers for their continued support. We greatly look forward to collaborating with you all over the next year and hope to see Personalized Medicine continue to grow and serve the research community in 2020.

\section{Financial \& competing interests disclosure}

E Torrington is an employee of Future Medicine Ltd, publisher of Personalized Medicine. The author has no other relevant affiliations or financial involvement with any organization or entity with a financial interest in or financial conflict with the subject matter or materials discussed in the manuscript apart from those disclosed.

No writing assistance was utilized in the production of this manuscript.

\section{References}

1. Personalized Medicine - Editorial Advisory Board. Future Medicine (2019). http://www.futuremedicine.com/journals/pme/editors

2. Kalra D. The importance of real-world data to precision medicine. Pers. Med. 16(2), 79-82 (2019).

3. Snyder J, Poisson LM, Noushmehr $\mathrm{H}$ et al. Clinical and research applications of a brain tumor tissue bank in the age of precision medicine. Pers. Med. 16(2), 145-156 (2019).

4. McCarthy J, Patrinos G. Educating healthcare providers in the delivery of genomic medicine. Pers. Med. 16(3), 187-188 (2019).

5. Ginsburg GS, Horowitz CR, Orlando LA. What will it take to implement genomics in practice? Lessons from the IGNITE Network. Pers. Med. 16(4), 259-261 (2019).

6. Moore JH, Boland MR, Camara PG et al. Preparing next-generation scientists for biomedical big data: artificial intelligence approaches. Pers. Med. 16(3), 247-257 (2019).

7. Edelman EA, Tanner PC, Taber KAJ et al. Provider engagement in precision oncology education: an exploratory analysis of online continuing medical education data. Pers. Med. 16(3), 199-209 (2019).

8. Hyland K, Garber K, Dasgupta S. From helices to health: undergraduate medical education in genetics and genomics. Pers. Med. 16(3), 211-219 (2019).

9. Easter C. Educating the public on genetics and genomics: Carla Easter speaks to Ebony Torrington. Pers. Med. 16(3), 195-197 (2019).

10. Tüzmen S, Hostetter G, Watanabe A et al. Characterization of farnesyl diphosphate farnesyl transferase 1 (FDFT1) expression in cancer. Pers. Med. 16(1), 51-65 (2019).

11. Wang Q, Peng WX, Wang L, Ye L. Toward multiomics-based next-generation diagnostics for precision medicine. Pers. Med. 16(2), 157-170 (2019).

12. Shamieh SE, Costanian C, Kassir R, Visvkis-Siest S, Bissar-Tadouri N. APOE genotypes in Lebanon: distribution and association with hypercholesterolemia and Alzheimer's disease. Pers. Med. 16(1), 15-23 (2019).

13. Twitter. Personalized med jnl (@fsgpme) (2019). https://twitter.com/fsgpme?lang=en 